\title{
ANALISIS PUTUSAN MAHKAMAH KONSTITUSI NOMOR 69/PUU-XIII/2015 TENTANG PERJANJIAN KAWIN*
}

\author{
Oleh: \\ Putu Astika Yasa** \\ Made Subawa*** \\ Bagian Hukum Bisnis Fakultas Hukum Universitas Udayana
}

\begin{abstract}
ABSTRAK
Dengan ditetapkannya Putusan Mahkamah Konstitusi Nomor 69/PUU-XIII/2015 tentang perjanjian perkawinan yang memperluas makna perjanjian perkawinan. Timbul persoalan baru yaitu bagaimana akibat hukum terhadap perjanjian sebelum dikeluarkannya perjanjian kawin dengan adanya putus Mahkamah Konstitusi. Penelitian ini menggunakan penelitian hukum yuridis normatif, dengan pendekatan perundangundangan (statute approach) dan pendekatan konsep (conceptualapproach) yang digunakan sebagai sumber dalam melakukan pembahasan. Hasil penelitian ini adalah perjanjian kawin yang dibuat sebelum berlakunya putusan Mahkamah Konstitusi adalah sah. Setelah adanya putusan Mahkamah Konstitusi, perjanjian perkawinan dapat dilakukan kapan saja dan terhadap perjanjian kawin yang dibuat sebelum berlakunya putusan Mahkamah Konstitusi adalah tetap menjadi perjanjian yang sah dan berlaku bagi para pihak yang membuatnya. Namun apabila pasangan suami isteri ingin merubah isi perjanian tersebut yang dulunya merupakan harta bersama dan menjadi harta masing-masing suami isteri dengan persetujuan bersama wajib mengantongi penetapan Pengadilan Negeri mengenai pemisah harta mereka. Seperti halnya penetapan Pengadilan Negeri Jakarta Timur Nomor 207/Pdt.P/2005/PN/Jkt.Tim dan Penetapan Pengadilan Negeri Jakarta Timur Nomor 459/Pdt.P/2007/PN/Jkt.Tim.
\end{abstract}

Kata Kunci: Perjanjian Perkawinan, Putusan, Akibat Hukum

\section{ABSTRACT}

With the enactment of the Constitutional Court Decision Number 69 / PUU-XIII / 2015 concerning the marriage agreement

${ }^{*}$ Analisis Putusan Mahkamah Konstitusi Nomor 66/Puu-Xiii/2015 Tentang Perjanjian Kawin adalah karya tulis ilmiah diluar ringkasan skripsi

${ }^{* *}$ Putu Astika Yasa adalah mahasiswa Fakultas Hukum Universitas Udayana

*** Prof. Dr. Made Subawa, S.H., M.S. adalah dosen Fakultas Hukum Universitas Udayana 
that broadens the meaning of the marriage agreement. A new problem arises, namely how the legal consequences of the agreement before the issuance of the marriage agreement with the Constitutional Court break up. This study uses normative juridical legal research, with a statute approach and a conceptual approach used as a source of discussion. The results of this study are marriage agreements made before the entry into force of the Constitutional Court ruling are valid. After the decision of the Constitutional Court, the marriage agreement can be made at any time and the marriage agreement made before the enactment of the Constitutional Court ruling is still a valid and valid agreement for the parties who make it. However, if the husband and wife want to change the contents of the agreement which was once a joint asset and become the property of each husband and wife with mutual agreement, they must pocket the stipulation of the District Court regarding the separation of their property. As for the stipulation of the East Jakarta District Court Number 207 / Pdt.P / 2005 / PN / Jkt. Team and Determination of the East Jakarta District Court Number 459 / Pdt.P / 2007 / PN / Jkt. Tim.

\section{Keywords: Marriage Agreement, Verdict, Legal Result}

\section{PENDAHULUAN}

\subsection{Latar Belakang Masalah}

Sesuai dengan kodratnya manusia mempunyai naluri untuk mempertahankan generasi atau keturunannya. Tentunya dalam hal ini cara yang paling tepat untuk mewujudkannya adalah dengan melangsungkan perkawinan. Nilai penting perkawinan bagi manusia adalah, pergaulan antara laki-laki dan perempuan terjadi secara terhormat sesuai kedudukan manusia sebagai makhluk sosial. Pergaulan rumah tangga dibina dalam suasana damai, tentram dan saling mengasihi antara suami dan isteri. Anak dari hasil perkawinan menghiasi kehidupan keluarga dan sekaligus merupakan anugerah dari Tuhan Yang Maha Esa.

Berdasarkan Pasal 1 Undang-Undang Nomor 1 Tahun 1974 Tentang Perkawinan (selanjutnya disingkat UU Perkawinan Tahun 1974), perkawinan didefinisikan sebagai "Ikatan lahir bathin 
antara seorang pria dengan seorang wanita sebagai suami isteri dengan tujuan membentuk keluarga (rumah tangga) yang bahagia dan kekal berdasarkan Ketuhanan Yang Maha Esa". Dalam Undang-Undang ini sudah jelas dijelaskan bahwa tujuan dari perkawinan tersebut adalah membentuk keluarga yang bahagia dan kekal, untuk itu suami isteri perlu saling membantu melengkapi, agar masing-masing dapat mengembangkan kepribadiannya, membantu dan mencapai kesejahteraan spiritual dan materiil.

Menurut cara pandang manusia terhadap perkawinan itu sendiri telah semakin kritis. Sebelum diundangkannya UndangUndang Perkawinan Tahun 1974, sangat sedikit para calon pasangan suami-isteri yang mengenal bahkan mengaplikasikan lembaga perjanjian perkawinan dalam ikatan perkawinan mereka. Namun dalam era kekinian, justru yang terjadi sebaliknya.

Perjanjian perkawinan adalah perjanjian yang dibuat oleh calon suami isteri sebelum atau pada saat perkawinan dilangsungkan untuk mengatur akibat-akibat perkawinan terhadap harta benda mereka. Dalam kaitan ini menurut R.Subekti, "perjanjian perkawinan adalah suatu perjanjian mengenai harta benda suami-isteri selama perkawinan mereka, yang menyimpang dari asas dan pola yang ditetapkan oleh undang-undang." 1

Perjanjian perkawinan sebenarnya berguna untuk acuan jika suatu saat terjadi konflik yang berakhir dengan perceraian, meski semua pasangan suami-isteri tentu tidak mengharapkan terjadi perceraian. Ketika pasangan harus bercerai, perjanjian itu

\footnotetext{
${ }^{1}$ Titik Triwulan Tutik, 2008, Hukum Perdata dalam Sistem Hitkitm Nasional, Ed. I, Get.
} I, Prenada Media Group, Jakarta, hlm.109. 
juga bisa dijadikan rujukan sehingga masing-masing mengetahui hak dan kewajibannya. Pada umumnya perjanjian perkawinan dibuat bilamana:

1. Terdapat sejumlah kekayaan yang lebih besar pada salah satu pihak dari pihak yang lain;

2. Kedua belah pihak masing-masing membawa pemasukan (inberg) yang cukup besar;

3. Masing-masing mempunyai usaha sendiri, apabila salah satu jatuh pailit yang lain tidak tersangkut;

4. Atas hutang mereka yang dibuat sebelum kawin, masingmasing akan bertanggung jawab secara sendiri-sendiri. ${ }^{2}$

Secara spesifik, perjanjian perkawinan diatur dalam Pasal 29 ayat (1), ayat (2), ayat (3), dan ayat (4) UU Perkawinan Tahun 1974 yang menyatakan bahwa suatu perjanjian perkawinan dapat dikatakan telah sah bilamana tidak melanggar batas-batas hukum, agama dan kesusilaan serta telah disahkan oleh pegawai pencatat perkawinan. Namun setelah dikeluarkannya putusan Mahkamah Konstitusi Nomor 69/PUU-XIII/2015 tentang perjanjian perkawinan yang mengakibatkan memperluas makna dari perjanjian kawin itu sendiri.

Berdasarkan putusan Mahkamah Konstitusi, kini perjanjian tidak lagi bermakna perjanjian yang dibuat sebelum perkawinan atau pada saat perkawinan dilangsungkan (prenuptial agreement) tetapi juga bisa dibuat setelah perkawinan berlangsung. Dengan demikian, putusan Mahkamah Konstitusi tersebut memberikan keleluasaan dalam mengadakan perjanjian perkawinan. Adanya

\footnotetext{
2 Sutanto, Tanpa Tahun, "Pengertian Perjanjian Kawin", URL: http://www.academia.edu.com, diakses pada tanggal 16 Januari 2019 
putusan Mahkamah Konstitusi ini akibat dari dikabulkannya permohonan Ike Farida secara bersyarat, seorang warga negara Indonesia yang menikah dengan warga negara Jepang. Mahkamah memberi tafsir konstitusional terhadap Pasal 29 ayat (1), ayat (3), dan ayat (4) UU No. 1 Tahun 1974 tentang Perkawinan. ${ }^{3}$

Persoalan yang dialami oleh pemohon a.n Ike Farida dalam pengujian Undang-Undang (judicial review) terhadap UndangUndang Dasar Negara Republik Indonesia Tahun 1945 (UUD NRI) pada putusan Mahkamah Konstitusi tersebut berkenaan dengan materi muatan dalam ayat, pasal dan/atau bagian UndangUndang yang dianggap bertentangan dengan UUD NRI. Pemohon mengajukan pengujian Pasal 21 ayat (1), ayat (3) dan Pasal 36 ayat (1) UUPA; Pasal 29 ayat (1), ayat (3), ayat (4) dan Pasal 35 ayat (1) Undang-Undang Perkawinan terhadap Pasal 28D ayat (1), Pasal 27 ayat (1), Passal 28E ayat (1), Pasal 28H ayat (1) dan ayat (4) UUD NRI. Substansi pasal-pasal dari dua Undang-Undang a quo yang hendak diuji adalah menyangkut hak-hak warga negara Indonesia yang kawin dengan warga negara asing yang tidak memiliki perjanjian perkawinan pisah harta untuk mempunyai Hak Milik dan Hak Guna Bangunan.

Berdasarkan Putusan Mahkamah konstitusi tersebut, kini pembuatan perjanjian perkawinan bisa disesuaikan dengan kebutuhan hukum masing-masing pasangan. Ike Farida, selaku pemohon, menyambut baik putusan MK, dan menyatakan putusan itu menyangkut kepentingan pelaku perkawinan.

Beranjak dari hal diatas tentu ada akibat hukum yang timbul dari adanya putusan tersebut yang mengakibatkan adanya

\footnotetext{
${ }^{3}$ Hukum Online.com, Plus Minus Putusan MK tentang Perjanjian Perkawinan Jangan sampai perkawinan sekadar dianggap sebagai hubungan kontraktual, http://www.hukumonline.com/
} 
permasalahan baru yang timbul. Permasalahan baru yang dimaksudkan yaitu bagaimana akibat hukum terhadap perjanjian yang dibuat sebelum adanya perjanjian kawin dengan berlakunya putusan Mahkamah Konstitusi tersebut.

\subsection{Rumusan Masalah}

Adapun rumusan masalah yang dapat diangkat dari latar belakang masalah diatas adalah sebagai berikut:

1. Bagaimana keabsahan perjanjian kawin yang dibuat sebelum keluarnya putusan Mahkamah Konstitusi Nomor 69/PUU-XIII/2015?

2. Bagaimana akibat hukum terhadap perjanjian kawin yang dibuat sebelum berlakunya Putusan Mahkamah Konstitusi Nomor 69/PUU-XIII/2015?

\section{ISI MAKALAH}

\subsection{Metode Penelitian}

Penelitian hukum ini menggunakan metode penelitian hukum yuridis normatif, yang dimana pada pembahasan menggunakan pendekatan peraturan Perundang-undangan yang berlaku (statute approach) sebagai sumber dari bacaan dan disamping itu juga pendekatan menggunakan bahan-bahan kepustakaan dan konsep-konsep (conceptual approach) yang ada juga menjadi sumber bahan hukum yang digunakan dalam melakukan pembahasan. ${ }^{4}$ Sumber bahan hukum yang akan digunakan adalah berupa bahan hukum primer yang berupa buku-buku serta kepustakaan lainya yang belum atau yang sudah

${ }^{4}$ Amiruddin dan Zanil Asikin, 2004, Pengaturan Metode Penelitian Hukum, PT. Raja Grafindo Persada, Jakarta, hal. 166 
ditelaah, kemudian dijadikan satu serta nantinya akan dikaitkan dengan rumusan masalah yang ada di dalam jurnal ini. ${ }^{5}$

\subsection{PEMBAHASAN}

\subsubsection{Keabsahan Perjanjian Kawin Yang Dibuat Sebelum Keluarnya Putusan Mahkamah Konstitusi Nomor 69/PUU-XIII/2015 Tentang Perjanjian Kawin}

Berdasarkan Undang-Undang Nomor 1 tahun 1974 tentang perkawinan pada Pasal 1 menjelasakan perkawinan adalah ikatan lahir batin antara seorang pria dan seorang wanita sebagai suami isteri dengan tujuan membentuk keluarga atau rumah tangga yang bahagai dan kekal berdasarkan Ketuhanan Yang Maha Esa.

Perjanjian perkawinan merupakan perjanjian yang dibuat oleh pasangan calon suami isteri sebelum maupun ketika perkawinan itu dilaksanakan yang bertujuan untuk mengatur akibat-akibat yang akan timbul dari perkawinan tersebut terhadap harta kekayaan dari pasangan suami isteri tersebut. ${ }^{6}$ Dalam peraturan di Indonesia perjanjian perkawinan sendiri diatur dalam Undang-Undang Nomor 1 Tahun 1974 Tentang perkawinan (UU Perkawinan). Dalam Dalam UU Perkawinan diatur dalam Pasal 29.

Melihat ketentuan-ketentuan ada dalam dalam Pasal 29 UU Perkawinan yang menjelaskan bahwa:

(1) Pada waktu atau sebelum perkawinan dilangsungkan oleh kedua belah pihak baik laki-laki dan/atau perempuan atas persetujuan bersama dapat mengajukan perjanjian secara tertulis yang disahkan oleh pegawai pencatat perkawinan,

\footnotetext{
5 Bambang Sunggono, 2010, Metode Penelitian Hukum, Rajawali Pers, Jakarta, hal. 86

6 Titik Triwulan, 2011, Hukum Perdata Dalam Sistem Hukum Nasional, Kencana Prenada Media Grup, Jakarta, hal.34
} 
setelah mana isinya berlaku juga terhadap pihak ketiga yang bersangkutan.

(2) Perkawinan tersebut dianggap tidak sah apabila melanggar batas-batas hukum, agama dan kesusilaan.

(3) Perjanjian tersebut mulai berlaku sejak perkawinan dilangsungkan.

(4) Selama perkawinan dilangsungkan perjanjian yang dibuat tidak dapat diubah, kecuali dari kedua belah pihak ada persetujuan untuk mengubah dan perubahan tersebut tidak merugikan pihak ketiga.

Dari ketentuan pada Pasal tersebut, dapat dimaknai bahwa dalam pemuatan perjanjian perkawinan calon pasangan suami isteri dapat membuat perjanjian perkawinan pada saat perkawinan dilangsukan maupun sebelum perkawinan tersebut dilaksanakan, apabila pasangan suami isteri berniat merubah perjanjian tersebut maka harus ada persetujuan bersama serta tidak merugikan pihak ketiga yang bersangkutan. Namun dalam hal membuat perjanjian perkawinan calon pasangan suami isteri dapat dengan bebasnya menentukan apa yang tertera pada perjanjian tersebut karena baik KUHPerdata maupun UU perkawinan tidak mengatur mengenai hal-hal apa saja yang dapat diperjanjikan.

Akan tetapi setelah dikeluarkannya Putusan Mahkamah Konstitusi mengakibatkan pengaturan mengenai perjanjian perkawinan yang berlaku di Indonesia menjadi bertambah yang dimana isi dari putusan Mahkamah Konstitusi pada intinya adalah perjanjian perkawinan dapat dilakukan kapan saja, baik sebelum perkawinan, saat perkawinan, dan setalah perkawinanpun masih dibolehkan membuat perjanjian perkawinan. 
Jadi terhadap perjanjian kawin yang dibuat sebelum berlakunya putusan Mahkamah Konstitusi adalah perjanjian yang sah dan berlaku bagi para pihak yang membuatnya apabila tidak melanggar ketentuan-ketentuan yang berlaku dalam UU Perkawinan.

\subsubsection{Akibat Hukum Terhadap Perjanjian Kawin Sebelum Keluarkannya Putusan Mahkamah Konstitusi Nomor 69/Puu-Xiii/2015}

Dalam Undang- undang Nomor 1 Tahun 1974 Tentang Perkawinan tidak diatur pembuatan Perjanjian Kawin setelah perkawinan dilangsungkan. Ketentuan dalam undang-undang tersebut hanya mengatur Perjanjian Kawin yang dibuat sebelum atau pada saat perkawinan dilangsungkan, namun dalam perkembangannya yang terjadi dimasyarakat sekarang ini dimungkinkan pembuatan Perjanjian Kawin setelah perkawinan yaitu dengan didasarkan Penetapan Pengadilan Negeri karena kenyataannya ada pasangan suami isteri yang karena alasan tertentu kemudian membuat perjanjian kawin setelah perkawinan dilangsungkan dengan Penetapan Pengadilan Negeri.

Pembuatan akta perjanjian perkawinan pada umumnya menimbulkan akibat hukum terhadap status harta maupun terhadap pihak ketiga yang berkepentingan. Akibat hukum terhadap status harta yang dulunya merupakan harta bersama menjadi harta masing-masing dapat dilakukan apabila pihak yang ingin hartanya dipisah sudah ada penetapan dari Pengadilan Negeri. Hal ini tercantum dalam Penetapan Pengadilan Negeri Jakarta Timur Nomor207/Pdt.P/2005/PN/Jkt.Tim terdapat dalam konsidran menimbang yang menyatakan "untuk melakukan 
pemisahan harta bersama diperlukan adanya penetapan dari Pengadilan Negeri".

\section{DUDUK PERKARA :}

Menimbang, bahwa Para Pemohon mengajukan permohonan tanggal 2 Mei 2005 terdaftar pada tanggal 4 Mei register perdata permohonan No : 207/Pdt/P/2005/PN.Jkt.Tim. sebagai berikut :

1. Bahwa Para Pemohon telah melangsungkan pernikahan pada tanggal 21-7-1997 sesuai dengan Kutipan Akta Perkawinan No.03/AA/1977;

2. Bahwa selama perkawinan tersebut Para Pemohon dikarunai dua orang anak;

3. Bahwa Para Pemohon sama-sama bekerja;

4. Bahwa Para Pemohon mempunyai penghasilan masingmasing yang cukup menopang kehidupan baik untuk kepentingan pribadinya maupun keluarga, sehingga baik Pemohon I dan Pemohon II tidak memerlukan bantuan dibidang ekonomi atau keuangan antara satu dengan yang lainnya, namun demikian dalam urusan keluarga Pemohon I tetap bertanggung jawab sepenuhnya atas kesejahteraan keluarganya sesuai dengan kedudukannya sebagai kepala keluarga;

5. Bahwa karena status sosial masing-masing sebagaimana tersebut di atas di mana pekerjaan Pemohon I mempunyai resiko terhadap harta bersama dalam perkawinan, karena pekerjaan Pemohon I mempunyai konsekuensi dan tanggung jawab sampai pada harta-harta pribadi, oleh karena itu Pemohon I dengan persetujuan Pemohon II berkehendak agar harta-harta atas nama Pemohon I dengan Pemohon II 
dan tetap menjadi milik pribadi Pemohon I, harta yang dimaksud adalah sebagai berikut :

a. Tanah dan Bangunan sertifikat Hak Milik No.00887, seluas 545 M2 terletak di Desa Jati Mulya, Kecamatan Kosambi, Kab. Tangerang, Jawa Barat;

b. Tanah dan Bangunan Sertifikat Hak Milik No. 00888, seluas $630 \mathrm{~m} 2$ terletak di Desa Jati Mulya, Kecamatan, Kosambi, Kab. tangerang, Jawa Barat;

c. Tanah dan Bangunan Sertifikat Hak Guna Bangunan No.154, seluas 288m2 terletak di Desa Dukuh, Kecamatan Cikupa, Kab. Tangerang Jawa Barat;

Demikian juga terhadap harta-harta lainnya yang akan timbul dikemudian hari tetap terpisah satu dengan yang lainnya sehingga tidak lagi berstatus harta campuran;

6. Bahwa seharusnya para Pemohon membuat perjanjian status harta bersama sebelum dilangsungkannya perkawinan, akan tetapi oleh karena kealpaan dan ketidaktahuan para pemohon sehingga baru sekarang, para pemohon berniat membuat perjanjian status harta bersama;

7. Bahwa oleh karena perkawinan antara Pemohon I dan Pemohon II telah dilangsungkan pada tanggal 21 Juli 1997, oleh karena itu untuk melakukan pemisahan harta bersama diperlukan adanya suatu penetapan dari Pengadilan Negeri;

Melihat duduk perkara diatas permohonan pemisahan harta ini dilakukan karena status sosial masing-masing pihak yang dimana pekerjaan suami dalam hal ini disebut pemohon I mempunyai resiko terhadap harta bersama dalam perkawinan, karena perkerjaan pemohon I mempunyai konsekuensi terhadap harta pribadi, oleh karena itu pemohon I dengan persetujuan 
pemohon II dalam hal ini adalah isteri berkehendak agar hartaharta atas nama pemohon I dengan pemohon II menjadi milik pribadi pemohon I.

Berdasarkan dari Penetapan Pengadilan Negeri Jakarta Timur Nomor 207/Pdt.P/2005/PN/Jkt.Tim dan Penetapan Pengadilan Negeri Jakarta Timur Nomor 459/Pdt.P/2007/PN/Jkt.Tim pasangan suami isteri dengan persetujuan bersama dapat mengajukan permohonan ke Pengadilan Negeri untuk pehisahan harta mereka apabila dikehendaki, bila tidak harta tersebut akan tetap menjadi harta Bersama. Dalam hal ini bahwa akibat hukum putusan Mahkamah Konstitusi terhadap perjanjian kawin yang dibuat sebelum keluarnya putusan Mahkamah Konstitusi adalah tetap memiliki kekuatan hukum mengikat bagi para pihak.

\section{PENUTUP}

\subsection{Kesimpulan}

sebelum adanya putusan Mahkamah Konstitusi peraturan yang mengatur mengenai perjanjian perkawinan di Indonesia terdapat pada UU perkawinan pada Pasal 29. Dapat dimaknai bahwa dalam dalam Pasal tersebut memuat perjanjian perkawinan calon pasangan suami isteri dapat membuat perjanjian perkawinan pada saat perkawinan dilangsukan maupun sebelum perkawinan tersebut dilaksanakan, apabila pasangan suami isteri berniat merubah perjanjian tersebut maka harus ada persetujuan bersama serta tidak merugikan pihak ketiga yang bersangkutan. Terhadap perjanjian kawin yang dibuat sebelum berlakunya putusan Mahkamah Konstitusi adalah perjanjian yang sah dan berlaku bagi para pihak yang membuatnya apabila tidak 
melanggar ketentuan-ketentuan yang berlaku dalam UU Perkawinan.

Setelah adanya putusan Mahkamah Konstitusi, perjanjian perkawinan dapat dilakukan kapan saja dan terhadap perjanjian kawin yang dibuat sebelum berlakunya putusan Mahkamah Konstitusi adalah tetap menjadi perjanjian yang sah dan berlaku bagi para pihak yang membuatnya. Namun apabila pasangan suami isteri ingin merubah isi perjanian tersebut yang dulunya merupakan harta bersama dan menjadi harta masing-masing suami isteri dengan persetujuan bersama wajib mengantongi penetapan Pengadilan Negeri mengenai pemisah harta mereka. Seperti halnya penetapan Pengadilan Negeri Jakarta Timur Nomor 207/Pdt.P/2005/PN/Jkt.Tim dan Penetapan Pengadilan Negeri Jakarta Timur Nomor 459/Pdt.P/2007 / PN/Jkt.Tim.

\section{DAFTAR PUSTAKA}

\section{Buku-Buku}

AbdulaRahman, 2003, Fiqh Munakahat, KencanaiPrenada Media Group, Jakarta.

Amiruddin dan Zanil Asikin, 2004, Pengaturan Metode Penelitian Hukum, PT. Raja Grafindo Persada, Jakarta

Bambang Sunggono, 2010, Metode Penelitian Hukum, Rajawali Pers, Jakarta

DjajaaS. Meliala, 2012, HukumaPerdata Dalam Prespektif BW, NuansaaAulia, Bandung

Titik Triwulan, 2011, Hukum Perdata Dalam Sistem Hukum Nasional, Kencana Prenada Media Grup, Jakarta

\section{Jurnal Hukum}

Dwinopianti, Implikasi dan Akibat Hukum Putusan Mahkamah Konstitusi Nomor 69/Puu-Xii/2015 terhadap Pembuatan Akta Perjanjian 
Perkawinan Setelah Kawin yang Dibuat di Hadapan Notaris, jurnal, Law Review, Volume IIX No.2 - Januari 2017

\section{INTERNET:}

DjajaaS. Meliala, 2012, HukumaPerdataaDalamaPrespektif BW. Get. I, NuansaaAulia, Bandung Hukum Online.com, Plus Minus Putusan MK tentang Perjanjian Perkawinan Jangan sampai perkawinan sekadar dianggap sebagai hubungan kontraktual, http://www.hukumonline.com/ diakses pada tanggal 1 agustus 2018

\section{PERATURAN PERUNDANG-UNDANG}

Undang-Undang Dasar Negara Republik Indonesia Tahun 1945

Kitab Undang-Undang Hukum Perdata

Undang-Undang Nomor 1 Tahun 1974 Tentang Perkawinan (Lembaran Negara Republik Indonesia Tahun 1974 Nomor 1) 